\title{
Communicative Pattern of Sebar Punjen Tradition in Srobyong Village, Jepara
}

\author{
Elly Fardzilatin ${ }^{1 *}$, Agus Subiyanto ${ }^{2}$ \\ ${ }^{1}$ Department of Linguistics, Faculty of Humanities, Diponegoro University, Semarang - Indonesia \\ ${ }^{2}$ Department of Linguistics, Faculty of Humanities, Diponegoro University, Semarang - Indonesia
}

\begin{abstract}
There are various cultures in Indonesia, one of which is the tradition of sebar punjen in the wedding ceremony. The aim of this research is to find out the communication patterns in the sebar punjen tradition. This study used qualitative research with ethnography of communication approach. In this study, researchers applied data collection techniques using observation, interview, record, and note. The data used in this study consisted of two types, namely primary data and secondary data. This research used Dell Hymes' SPEAKING theory. The results of this study indicate that there is a communicative situation in the tradition of sebar punjen. That tradition is performed at the house of the bride with the last child and is held at night. This communicative event is preceded by an opening which is done by the elders, the parents of their son-in-law, and the grandchildren then form a line. Elders give advice to their children, childrenin-law, and grandchildren. After the prayer from the elders is finished, the line goes around uborampe (offerings) in unison. Then the elders spread coins mixed with yellow rice and spices to relatives and neighbors and then scramble to take coins.
\end{abstract}

\section{Introduction}

Indonesia has been a diverse country consisting of many cultures, ethnicities, customs, and religions. Culture is an idea or action and a human being who produces work for the life of society that is made into a human being for learning. Javanese culture has much diversity to inspire Javanese people in their actions or behavior. From the much diversity that Javanese people possess, this community has its uniqueness. They usually take all actions that cannot be separated from the tradition or habit adhered to by their elders for a long time. The uniqueness that exists in Javanese society can be seen from the community's trust, language, arts, and traditions. The Javanese people are one of the ethnic groups in Indonesia who are proud of their culture.

The wedding procession in Javanese customs has its symbols still related to life, a life that reveals human behavior and feelings through various traditional ceremonies. This traditional Javanese marriage is very famous for its complexity, starting from the prewedding, the marriage procession, until post-wedding. The action is by the customs of the

\footnotetext{
* Corresponding author: ellyfardzilatin@gmail.com
} 
place. This wedding ceremony is the formation of a new independent family and can be a way to forge kinship.

The tradition and culture of the Javanese people that are still maintained and carried out by some people, especially the people of Central Java, is the tradition of sebar punjen. This punjen marriage tradition is one of the most critical moments for parents who marry off their last child. The tradition of sebar punjen is a form of gratitude for the completion of parents' duties. Jepara is one of the cities located in Central Java, which still maintains and uses the tradition of sebar punjen.

This ritual communication can be interpreted as a process of meaning in a message within a group where there is a religious activity and the belief system it adheres to. In each process, there is always a clear and definite meaning of particular symbols that indicate a communication process and rituals [1]. The communication process in this ritual often occurs in competition with formal religious understanding, which then has customs in the process. This ritual activity is one of the many customs in culture. It is carried out by a specific community group which becomes what it has obtained or requests for safety, convenience, and smoothness in everything it will do.

This communication ethnography is what looks at behavior that starts from birth. From integration, there are three skills that each individual has as a social being. These three skills are linguistic skills, interaction skills, and cultural skills (Kuswanto, 2008) [2]. Mulyana says that the explanation of the rituals held in human life. Humans experience various kinds of traditions, from birth to death. Each region has its traditions, which have their uniqueness. That uniqueness can emerge from anywhere, such as verbal and non-verbal language, the sequence of formal events, and the surrounding natural conditions [3].

This research was conducted to determine the ethnography of communication that occurred in the tradition of sebar punjen. It brought up the discussion about the culture or tradition of punjen weddings in Srobyong Village. This study would use an ethnographic approach to explain every detail of the tradition. The purpose of this study was to determine the communicative situation, communicative events, and communicative acts in the tradition of sebar punjen in Srobyong Village, Mlonggo Sub-district, Jepara Regency.

The research conducted by M. Rifa'I (2017) [4] discusses traditions entitled "The Communication Ethnography of Tingkeban Neloni Ritual and Mitoni: the Study of Ethnographic Communication for Javanese Ethnics in Sumbersuko Village, Gempol District." The results of this research show the discovery of seven-month ritual communication. That ritual activity is carried out at home. It can also be done at the home of the parents of the prospective father. The communicative events in this seven-month ritual have topics, purposes, settings, participants, message forms, message content, action sequences, interaction rules, and norms. In communicative activities like this, those who know the details and understand the seven-month implementation are the seven-monthly presenters (tingkeban).

Hastika Indriyana (2016) [5] examines the ethnography of communication in inter-ethnic marriage customs. The results of this study can be seen from the results of the research. There is a communicative situation in Javanese and Lembak traditional marriages, namely at the time of application where the brides welcome the groom's family. The marriage contract and pijak telur (stepping on the egg) symbolize the beginning of life in a family that can produce future generations, sungkeman (kneeling) functions to ask for blessings from both parents, and dahar klimah symbolizes that the bride and groom will live side by side in every situation. In addition, another communicative act that can be found from the ceremony is the delivery of messages (advice) from the elders to the bride and groom about living in harmony in the household even though they come from different ethnicities.

Gumisrti Awalia (2019) [6] research discusses the ethnography of traditional communication on six holidays in the Island Village, Bangkinang Sub-district. The result of 
this research is that there is a communicative situation in the tradition of the sixth day of Ramadhan. The second is the occurrence of a communicative event which includes a whole series of components that build communication. There is a genre or type of event, topic, purpose, the function of the arrangement, participants, message content, action sequences, rules of interaction, and norms of interpretation in the sixth Ramadan day tradition. Meanwhile, communicative actions describe all ongoing communication activities which are unique or distinctive characteristics of the Sixth Ramadan Day Tradition, namely during pilgrimages from the Bangkinang community of various social status and age groups. They move together towards the cemetery in the District of the Island and surrounding areas.

Research conducted by Elvi Susanti (2015) [7] examines the communication of sevenmonthly traditional rituals (ethnographic study of Central Javanese ethnic Bai communication in Pengarungan Village, Torgamba Sub-district, South Labuhan Satu Regency, North Sumatra). The results of this study indicate that there is a communicative situation in this seven-month event. It is held at home or the parents' house and is attended by parents, neighbors, and members of the Pengarungan community. This communicative event is based on genre, type of event, topic, purpose, function, setting, participants, message content, and interaction rules. There are also interaction and interpretation norms. This communicative situation is a person who knows and understands the flow and its meaning. The implementation of these seven monthly events is the host of the event in seven months. Research conducted by Yohana Nova (2015) [8] rules of communication interaction basiacuang oral tradition in traditional marriage Malay Kampar Riau. The basiacuang oral tradition in traditional marriage ceremonies in the Kampar Malay speech community in Kuok Village, Kuok District, Kampar Regency, Riau Province is included in customs and traditions inherited from generation to generation from ancestors. This tradition takes the form of performances and social functions in the Kampar Malay community. The method used is a qualitative method with an ethnographic approach to communication. This study indicates that the basiacuang oral tradition prioritizes the beauty of the language used by speakers. The rules of social interaction in the basiacuang oral tradition will succeed depending on the speaker's expertise and fluency in applying the values in the basiacuang oral tradition. This basiacuang cultural rule, in which each utterance contains will contain the expressions of petatah-petitih and also rhymes which have philosophical meanings, values, and norms in the life of the Kampar Malay community, Riau Province.

This research is seen from several journals above, written by other researchers. Those previous researches can be concluded as discussing the problems of Javanese customs or traditions. However, the topic raised by the author is different. The author raises the topic about sebar punjen tradition by using an ethnographic study of communication.

\section{Research Methods}

This study used a qualitative research method using an ethnographic approach to communication. According to Sukmadinata (2006: 72) [9], descriptive research aims to describe existing phenomena, both natural phenomena and artificial phenomena. Data collection in this study applied observation, interview, record, and note techniques [10]. The researchers used primary data. The authors obtained the primary data through direct observation and interviews with community leaders (elders) who lead the way the sebar punjen tradition and people who know about it. The researcher used Dell Hymes' SPEAKING theory [11].

S: Situation setting: the concrete physical state of a communicative event.

P: Participants, speakers (people who deliver messages), recipients (people who receive messages), addressers (people who deliver messages or sources), and audiences (people present when the message is communicated, but indirectly). 
E: End/result: the event's objective from a cultural or community point of view.

A: Action sequences include content and form (descriptions of sequences or communicative actions).

$\mathrm{K}$ : Keys, attitudes, certain types of behavior, gestures, postures, and parts.

I: Instrumentality, including the channel (how the message travels).

$\mathrm{N}$ : Norms, including interactions and interpretations.

G: Genre (recognizing communicative events with a common goal).

\section{Result and Discussion}

In the traditional wedding ceremony, the sebar punjen has three critical points: communicative situation, communicative event, and communicative action. These three elements would be analyzed using Dell Hymes' SPEAKING theory.

The communicative situation is the situation. The tradition of sebar punjen is carried out at the bride and groom's house with the last child. This event is usually carried out at night, leading to the change of day-usually, around 23.30, equipped with ubarampe (offerings). Participants in the sebar punjen tradition are the nuclear family consisting of parents, children, son-in-law and grandchildren, relatives, and neighbors. This communicative event occurs when the child gives his gratitude to the parents, then the father replies, and the elders (who lead this event) advise the child, son-in-law, and grandchild.

This research will discuss the implementation of sebar punjen tradition. The communicative action is in advice so that children, son-in-law, and grandchildren get along well without jealousy. In sebar punjen, the nuclear family is gathered together in the house's yard, then forms a row from the first child to the last child. Elders advise the following sentences:

Kakang, adhi lan tangga, acara tradisi sebar punjen ing griya pak anjar sakluwargi ingkang pungkasan sampun menikahkan lare perempuanipun ingkang naminipun (namaning penganten putri) ingkang angsal (namaning panganten jaler) lan pak anjar puniki mensedakahkan kalih sadayaning lare putunipun amargi supados mboten wonten raos iri sesami sadherek. sebar punjen puniki inggih punika ingkang pungkasan sasampunipun puniki sampun mboten nggadhahi acara kangge menikahkan larenipun. amargi puniku disedekahkan kalih lare putunipun supados mboten wonten ingkang nuntut kalih embah putri lan embah kakungipun.

'Brothers, sisters, and neighbors, the traditional program of sebar punjen at the house of (name of the person who holds that event) who is marrying off his daughter named (name of the bride) who gets (name of the groom) and (name that has the event) is held, giving alms to all of their children and grandchildren so that there is no jealousy among siblings. This sebar punjen is the last. After this time, there is no event to marry off their children anymore. It is given to children and grandchildren so that no one sues the grandmother and grandfather.

At the opening made by the elder before going to the core of sebar punjen, namely in the first sentence, it is explained that sebar punjen would be done at the house of someone who holds the wedding ceremony. The elder introduces what sebar punjen is and the purpose of doing sebar punjen. He also explains the parents who give away their property or money by symbolizing coins so that their children and grandchildren would not jealous of their fellow brothers and sisters.

Mugi-mugi emah-emahipun puniki dados keluwargi ingkang sakinah mawaddah warahmah. mugi-mugi enggal nggadhahi keturunan, saras walafiat, iman lan Allah SWT Al-fatihah. 
'Hopefully, this marriage will be sakinah mawaddah warahmah family. Hopefully they will soon have offspring, be in good health, and faith in Allah SWT. Al-fatihah.'

Then what this elder said contained a prayer of kindness for the bride to be a sakinah mawaddah warahmah family. The sentence's meaning is to become a calm, serene, peaceful family filled with a sense of love and affection. That wish is also for immediate children or offspring, always be healthy, and have added faith in Allah SWT. They then read Surah AlFatihah together.

Sebar ponjen inggih punika simbol ajeng tanggel jawab tiyang sepuh lebet nguculi sadayaning larenipun lebet mengarungi seganten kegesangan. arta receh puniki inggih punika simbol persembahan tiyang sepuh nggih materi utawi mboten materi lebet ngajengi dinamika kegesangan manungsa.

'Sebar Ponjen is a symbol of the responsibility of parents in releasing all their children in crossing the oceans of life. Doit or small money is a symbol of parental offerings both material and non-material in facing the dynamics of human life. '

Said by the elder, it is explained that the sebar punjen is a symbol of the responsibility of the parents that have been completed to their children or it could be said that the parents release their children to have their own families with their partners. The two elders explain about money which is a symbol of the parents' property that is given to their children. It is both material and non-material for provisions in facing their future life with their respective families.

Lare pertami dipunsukakaken arta (sedekah) supados (upaminipun damel saged bidhal kaji, nyambut damelipun barokah.)

"The first child is given money (alms) so that he can go to Hajj, his work is blessed."

The elders explain the symbol that is given to the first child who has this event (this prayer is seeing the situation of the first child's family). For example, there is a prayer explaining that so that the family of the first child can go to Haji. His work so far and in the future is also hoped to be blessed. The meaning of the word "barokah" here has the meaning that the work can develop or increase.

Lare kaping kalih dipunsukakaken arta (sedekah) (upaminipun damel saged kangge usaha bidhal kaji, saget ndamel griya, saget gadhah mobil, dilancaraken babaran lare kapeng kaleh ibu lan larenipun selamet lan mboten kirang punapa mawon.)

"The second child is given money (alms) and wished to be able to go to hajj, have blessed work, repair the house, buy a car, and deliver the child in which both mother and child for subs and nothing less."

The elder explains the symbol that the parents give to this second child, namely the wish stating that the family of this second child is able to go on a family pilgrimage, have a house or build his own house, buy a car, and deliver a baby - in which the birth process of this second child can run smoothly. The mother and child are healthy and there are no obstacles whatsoever. 
Lare kaping tiga dipunsukakaken arta (sedekah) (upaminipun enggal angsal keparingan lare ingkakng soleh lan siolehah, damel usahanipun tambah berkah lan saged bidhal kaji sekeluarganipun kaping kalih).

"The third child is given money (alms) and immediately gets a pious child. His business is more blessed and he can leave for the second hajj of his family."

Elders explain the symbol of parents' gift to this third child. The third child's family is expected to have pious children or descendants immediately. Their business is also hoped to be blessed so that the family of this third child can go on the pilgrimage for the second time.

Lare kaping sekawan dipunsukakaken arta (sedekah) (upaminipun saget ngrencangi dandosaken griya, enggal gadhah lare ingkang soleh lan solehah, mundhut mobil, mugimugi angsal enggal bidhal haji. Angsal didadosake dados pawitan kangge pasangan penganten kangge penganten mengarungi batera penganten griya tangga)

'The fourth child is given money (alms). I hope this can help to improve the house, soon have children, can buy a car, and we can go to Hajj. It can be used as capital for the bride and groom to navigate the domestic bride's ark. '

This elder explains the symbol of parents' gift to the fourth child (the last one to become a bride). It is wished that the child can renovate the house he would live in to be more comfortable if occupied, immediately have pious children or descendants, buy a car, and go or depart for the pilgrimage. Hopefully, what the parents give can help the newlyweds to navigate the household ark. The meaning of this household ark sentence is that you can form a family with the hope that it will continue to death even afterlife in this world will end. Thus, marriage is a sacred bond.

When this elder speaks to the first child to the fourth (last) one, he also performs communicative actions. It is done not only by verb acts but also by nonverbal actions in this sebar punjen tradition. This non-verbal communicative act is in the form of a symbol showing gift of coins in a bag. That bag contains coins, yellow rice, herbs, or spices. The meaning of a bag of coins given to the children can also be interpreted as spices. It can symbolize maintaining health so that the family is always healthy. This yellow rice can be a symbol for maintaining health. This coin can symbolize sincere nature. The bags, which are distributed and not distributed and distributed in an orderly manner, can symbolize that they will not seize the rights of others (usurp the rights of their siblings) and like to help in families who have difficulties.

Salajengipun arta receh disebar kalih sadherek-sadherek lan tangga ingkang dugi lan ing pendhet kalih rebatan kalih sadherek lan tangga ingkang dugi.

"Then the coins were distributed and grabbed by the relatives and neighbors who were present."

Then these elders throw coins to relatives and neighbors who participate in enlivening this event. The money distributed to relatives and neighbors is different from the ones given to the children. It is also a symbol of charity to relatives and neighbors. After throwing the coins, the sebar punjen tradition is over. The communicative acts performed by the elders are not only verb acts but also nonverbal. 
In this nonverbal speech act, the elders throw coins, spices, and yellow rice that had been put together with the coins to be thrown or distributed evenly to the relatives and neighbors who are present to enliven the sebar punjen.

This sebar punjen tradition uses verbal and nonverbal communicative actions. When showing this action verb, Elders use precise intonation so that the listener can understand what the sayings are. Furthermore, the elder's nonverbal action is that he provides small bags set according to the number of children. The bags, which contain coins, yellow rice, and spices and symbolize gifts from parents to their children, would be given one by one. The language used by the elders to these participants is Javanese (krama).

This sebar punjen tradition is the advice of parents to their children always to work diligently, maintain health and cleanliness, have a sincere nature, avoid seizing the rights of others, and get along well with all their families and those who need help-especially in living life in the new household. This sebar punjen also indicates that the duty or obligation as a parent to their children has been completed, and there is no need to marry off their children because all of the children are married. This event is carried out to maintain the traditions of the Javanese people that have been passed down from a long time ago. It is still preserved and can be carried out in future generations. Communicative action in this sebar punjen tradition is advising children, son-in-law, and grandchildren.

\section{Conclusion}

From the discussion about sebar punjen above, it can be concluded that this tradition is carried out at the house of the bride or groom, who is the last child of a family. It is usually held at night towards the turn of the day. Usually, around 23.30, equipped with ubarampe (offerings). Sebar punjen, has a communicative event, namely the advice of elders to children, sons-in-law, and grandchildren. This is the main focus of sebar punjen. The process of elders advising the children, children in law, and grandchildren are still harmonious in social ways. Sebar punjen contains parents' advice to their children always work diligently, maintain health and cleanliness, have a sincere nature, avoid seizing the rights of others, get along well with all their families, and become helpful for everyoneespecially in living life in the new household. This sebar punjen also indicates that the duty or obligation as a parent to their children has been completed, and there is no need to marry off their children because all of the children are married. There is a symbol of bags containing coins, yellow rice, and herbs or spices. The meaning of a bag of coins given to this child can also be interpreted as spices, yellow rice, and coins. This pouch package provided is not distributed, and the distribution to the orderly and this sequence has a meaning. It can be seen that natural life and culture cannot be separated.

\section{References}

1. M. S. Troike. The Ethnography of Communication, an introduction. (2003)

2. K. Engkus. Etnografi komunikasi. (2008)

3. Mulyana. Ilmu Komunikasi suatu Pengantar. Bandung Remaja. Rosdakarya (2005)

4. M. Rifa'i. E. 2. 3. (2017)

5. I. Hastika. J.P.F.U. $3.2(2016)$

6. A. Gumisrti. J.F 6. I (2019)

7. E. Susanti. J.F. 2. (2015)

8. Y. Nova. J.P.K. 18. 46. (2015) 
9. $\quad$ SN Syaodih. Metode Penelitian Pendidikan. 72. (2006)

10. M. Deddy. Metodologi Penelitian Kualitatif. (2004)

11. H. Dell. Foundations in sociolinguistics: An Ethnographic Approach. (1974) 